\title{
Experiments with a University e-Participation Platform
}

\author{
Víctor F. Peñafiel1', Javier F. Guerrero², José M. Lavín³ \\ ${ }^{1}$ Direction of Research and Development, Technical University of Ambato, Ambato, Ecuador \\ ${ }^{2}$ Dept. of Computer and Systems Sciences, Stockholm University, Stockholm, Sweden \\ ${ }^{3}$ Faculty of Jurisprudence and Social Sciences, Technical University of Ambato, Ambato, Ecuador \\ Email: vi.penafiel@uta.edu.ec, javier@dsv.su.se, josemaria.lavín@gmail.com
}

How to cite this paper: Peñafiel, V.F. Guerrero, J.F. and Lavín, J.M. (2017) Experiments with a University e-Participation Platform. Social Networking, 6, 239-249.

https://doi.org/10.4236/sn.2017.63016

Received: May 25, 2017

Accepted: July 15, 2017

Published: July 18, 2017

Copyright (C) 2017 by authors and Scientific Research Publishing Inc. This work is licensed under the Creative Commons Attribution International License (CC BY 4.0).

http://creativecommons.org/licenses/by/4.0/

\begin{abstract}
Currently, the ICT put at our disposal is increasingly more powerful tools that can help increase citizen participation, transparency, and legitimacy in decision-making. We understand that these participation tools can break down into a set of tasks. In this dissertation, we review some of these tasks and how we can integrate them into a series of processes in public higher education institutions. By establishing the tasks, we can set up an online architecture for electronic participation and support for decision-making within the university community. One of the consolidated database architectures we have used for this study is MyUniversity-URJC. This proposal is achievable by utilizing the Universities' technological infrastructure and, mainly, the digital culture of its users.
\end{abstract}

\section{Keywords}

ICT, Electronic Democracy, Citizen Participation, Web Architecture

\section{Introduction}

The growing development of technology and in particular the Internet can allow higher citizen participation and implication of public decision-making. In this sense, the information and communication technologies (ICT) contribute new possibilities to public participation, increase transparency and legitimacy in decisions, improving the digital and political culture [1]. One of those possibilities is increasing the number of individuals in the public participation process [2]. We see that the ICT cannot only be applied for public policy, but also in universities.

The different studies carried out worldwide show that the current figures for student participation in universities are low [3] [4]. Likewise, student participa- 
tions in the governance of the University are addressed by the work done by Menon [5] and Persson [6], whose research is aimed at increasing student participation. Therefore, it is proposed to encourage and facilitate, through the inclusion of student participation in the different governing bodies in the University and in decision-making at different levels. A large number of participatory tools with electronic support what exists currently, the "ad hoc" methodologies, can enable these steps. We understand that the participatory tools are a combination of basic participation tasks [7]. In this sense, the tasks that are executed within Technical University of Ambato [Universidad Técnica de Ambato (UTA)] are, generally, those found in any higher educational entity. Thus, our intention is to electronically support processes of participation within the University, whose purpose is not only to improve participation but also to reduce, what is called "democratic deficit" [8] in universities. Among the experimental tools based on web services, we have the platform MyUniversity. The objective of this study is to increase student participation and improve the quality of it, through the platform MyUniversity-URJC.

\section{MyUniversity}

MyUniversity is a pilot project focusing on the unification of European higher education and its effect on university players (students, teaching, and administrative staff), whose purpose is to create added value from the use of certain technologies. MyUniversity contains a number of participatory tools for any kind of decision-making. Also, the administration and development of the platform is executed within the framework of the European project MyUniversity: Decision making for a united higher education. MyUniversity can make it possible to discuss relevant issues in a problem that uses group decision making [9], problem structuring, voting, mediation, etc. In addition, the support methodology used to solve a problem is the cycle of Decision Analysis [10], to which methods are added to support groups. Thus, it helps achieve better understanding of a problem and properly structured thinking and communication within the group.

MyUniversity is based on an adapted version of the citizen platform Demos@Work [11], see Figure 1.

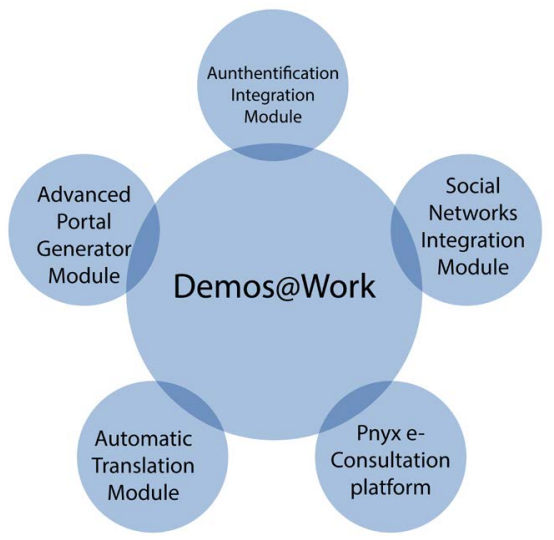

Figure 1. Demos@Work. Source: Advanced version technical description D2.6. 
Demos@work consists of an advanced portal to generate modules; a module for user authentication, a module for integration with social networks, an automatic translation module, and an electronic consultation platform.

The main portal or master serves generate new sub-portals which can be automatically produced in case new universities want to be added to the project. Every portal has a Back-end and a Front-end. The Back-end represents the administrative interface for portal management. The Front-end is the user interface. The user authentication module incorporates mechanisms of LDAP, OpenID, and authentication of Gmail. This allows each portal administrator to activate and configure one or more of these plugins, integrating its subportal with other authentication systems. The integration module with social networks incorporates Facebook and Twitter, which means you can publish the information in the portals as modules. At the same time, the information of the portals (news articles, participation processes) can be spread through these social networks. In addition, there is the automatic translation module that can translate the entire site content. It supports more than 40 languages. The electronic consultation platform has a portal for users to express their opinions and a back office that allows system administrators to configure and set up e-consultation processes. The modules include participatory tasks such as debate, voting, sampling, dissemination of information, explanation for the users, preparation of final documents, use of questionnaires, among others, see Figure 2.

The following universities participated in this proyect: Rey Juan Carlos (URJC), Barcelona, Stockholm, Girona, Lleida, Cataluña Polytechnic, Slovak agriculture in Nitra, Presov, Bussines International School of Bulgari, National

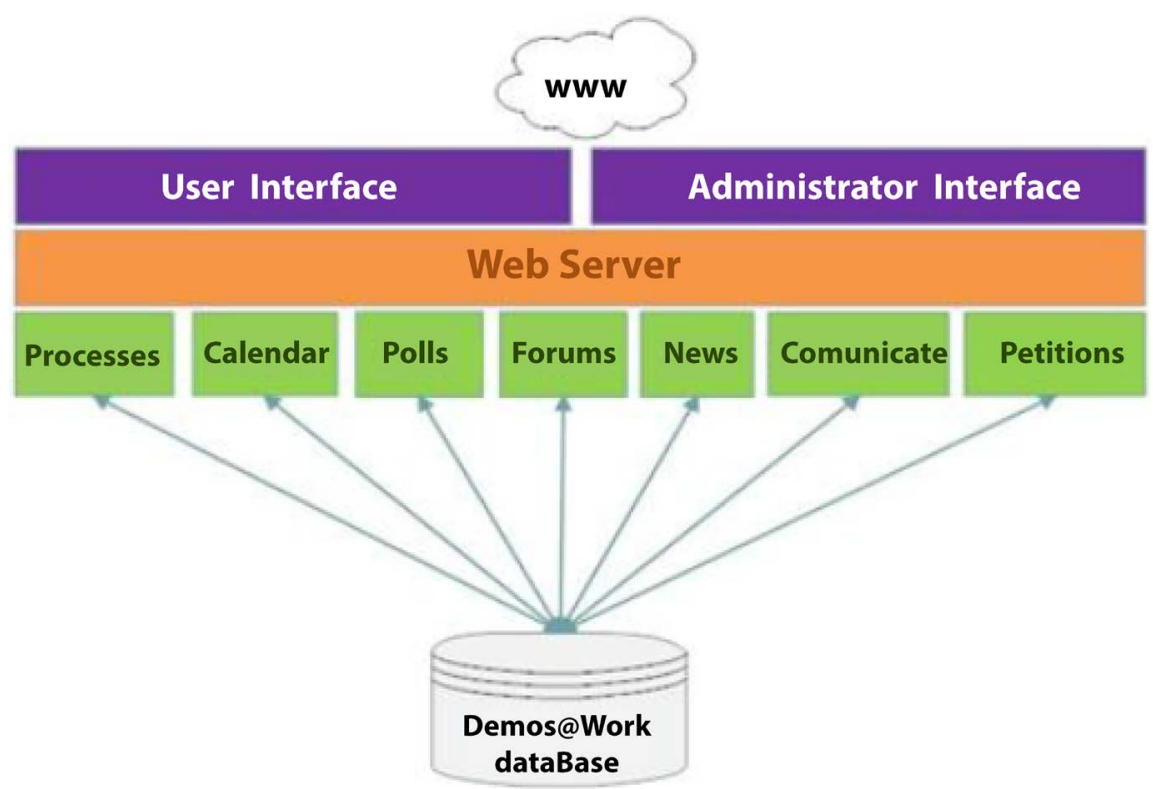

Figure 2. Technical model of the version used in MyUniversity. Source: Advanced version technical description D2.6. 
and World Economy, León, Slovak technology in Bratislava, Vilnius. In the proyect, each of these universities had its own portal, thus, MyUniversity-URJC. Thus, the platform performed various online participative tasks with the aim of improving the decision-making processes, consequently, the legitimacy and transparency. In this sense, there was a greater belonging to all the university stakeholders.

Finally, regarding UTA, the use of MyUniversity permitted to improve a series of processes such as participation and web consensus, a well-organized communication, debate and idea sharing, impulse in the use the ICT, among others. Additionally, on one side, it not only let to update the instruments as well as to make them more efficient but also to improve the transparency in the decision-making process. On the other side, the increase of participants' satisfaction.

\section{Methodology}

Employing, using the modules that MyUniversity-URJC uses, four events were executed experimentally. It should be mentioned that from all universities stated in the project, UTA is the only one that has truly applied the prototype for this investigation. For the debate experiment, participatory tasks like information dissemination, debating, voting, explanation (to the university community) was used. For the sharing and information exchange experiment, participatory tasks such as dissemination of information, debate, voting, preparation or generation of final documents, explanation (to the university community) was used. In the embodiment of the voting experiment, we had participatory tasks such as dissemination of information (presentation of candidates), debate, voting, and explanation (to the university community). As for the sampling experiment, we used participatory tools such as dissemination of information, use of questionnaires, sampling, and explanation (to the university community). In addition, all processes performed with MyUniversity-URJC were developed using a client/ server model. Thus, the administrator of each university works from the Frontend of their own portal, but at the same time it is controlled by a "super administrator" from MyUniversity from the Back-end.

\section{Experiments and Results}

This paper describes in detail a field study that was conducted by applying a satisfaction survey to students, teachers and authorities of the UTA about the use of MyUniversity. The population considered for our study was the Faculty of Health Sciences [Facultad de Ciencias de la Salud (FCS)]. The students involved were in the first and second semesters of the School of Medicine. The graduates of the last class of Medicine also participated. Likewise, the members of the FCS Board of Directors were included. The goal was to conduct four experiments like the debate on the use of the platform MyUniversity, decision-making in the Board of Faculty of Health Sciences, election of President and Vice-President in parallel to the School of Medicine, and a survey to obtain information about the degree of academic satisfaction of graduates from the last class of Medicine 
(sampling). Beforehand, the groups involved in the e-participation received training for the use of the platform MyUniversity-URJC. The complete sample was with 76 people. For the debate and voting experiment, 26 and 19 students respectively were intervened. In the decision making of the Faculty Board, 9 members participated. For the sampling 22 graduates participated. After these events, the respective satisfaction survey was applied. For that, six items were used. Questions 1, 2, and 5 used a closed scheme and Questions 3 and 4 were multiple-choice semi-closed. Only Question 6 used the Likert scale [12]. In addition, the survey that was applied was anonymous and face-to-face. Later, the data was tabulated using SPSS. Next, we presented the results of the experiments performed with MyUniversity-URJC at the Technical University of Ambato.

After having analyzed and debated the topic we asked: Is this tool applicable to the Ecuadorian university environment? In Figure 3 the results of the debate are observed.

The group in general did think this tool is applicable to the Ecuadorian university environment. Which means that the traditional mechanisms used in the University can be better executed with the support of the ICT, whose electronic support is in the web. We see that the participants are motivated to implement their skills, abilities, knowledge acquired in their digital training.

In Figure 4 we present the results of decision-making in the Directing Council of the FCS.

The Directing Council of the Faculty of Health Sciences of the UTA, issued some guidelines to the case presented by the student. In this case, they determined "Ask the graduate of the class to restructure the topic presented for the development of the research project, prior to obtaining the title of Graduate".

In Figure 5 for the task of e-voting, we observed that $81 \%$ corresponding to 13 students, have shown their preference for the candidates who make up the first choice.

The remaining percentage is distributed among the other participating bino-

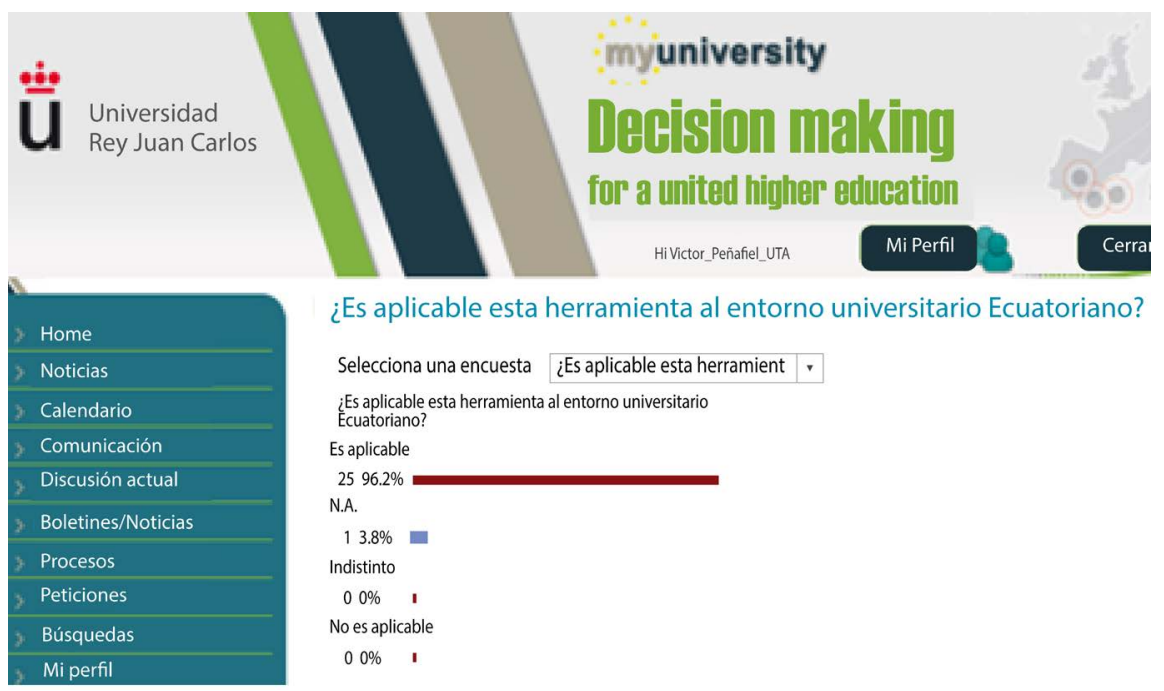

Figure 3. Results of the debate. Source: MyUniversity-URJC. 


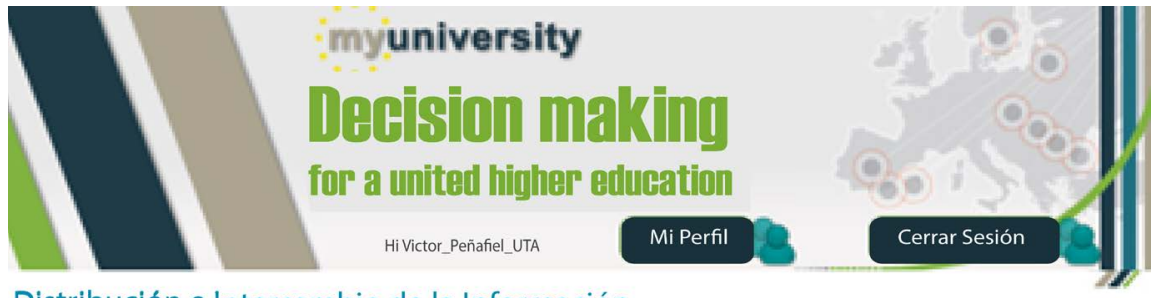

Distribución e Intercambio de la Información

El Consejo de Departamento de la Universidad Técnica de Ambato es el organismo colegiado responsable de inspirar, impulsar, planear, dirigir, dar seguimiento y evaluar la marcha general del departamento, en diálogo y coordinación con el Jefe, dentro del marco de las políticas, normas y decisiones de la institución y sus instancias de autoridad.

Tema de debate $\quad$ Respuestas Fecha

Figure 4. Results of decision-making. Source: MyUniversity-URJC.

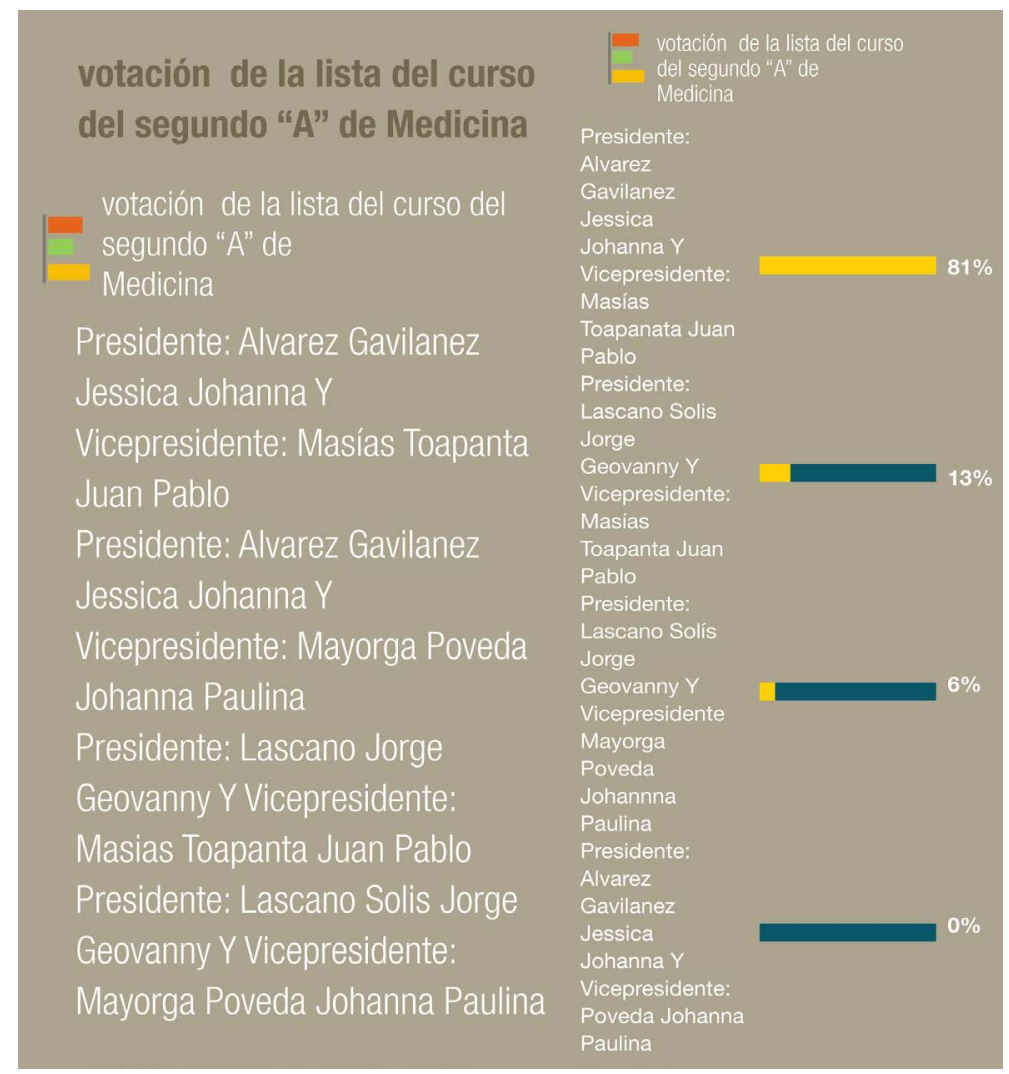

Figure 5. Results of the electoral process. Source: MyUniversity-URJC.

mials, which concerns 3 students.

In Figure 6 we observed the questionnaire for the sampling task. Thus, in the first section that refers to the organization of the curriculum, graduates express that in general it has been very good.

As for the questionnaire, it was uploaded to MyUniversity-URJC, see Figure 7.

In the following section concerning career objectives, participants think that the program contents were well selected, but they believe the system for assessing the students was not. In what corresponds to the school life section, most 


\begin{tabular}{|l|}
\hline ORGANIZACIÓN DE CURRÍCULO \\
$\begin{array}{l}\text { 1. El interés de la Administración de Escolar y los Docentes con relación } \\
\text { al estudio, planeamiento y evaluación del currículo } \\
\text { OBJETIVOS DE LA CARRERA }\end{array}$ \\
2. En lo que respecta a los contenidos programáticos de carrera \\
\hline 3. Cree ud que los contenidos de la carrea fue: \\
\hline $\begin{array}{l}\text { 4. Cuál es su opinión sobre el sistema adoptado, para evaluar el } \\
\text { rendimiento de los estudiantes en la carrrera. }\end{array}$ \\
\hline $\begin{array}{l}\text { VIDA ESCOLAR } \\
\text { 5. Cual es su opinión al respecto sobre la integración de } \\
\text { los estudiantes duarnte la carrera }\end{array}$ \\
\hline 6. La relación de los estudiantes con el profesor, fue:: \\
\hline EVALUACIÒN DEL PROCESO DE LOS ALUMNOS \\
\hline $\begin{array}{l}\text { 7. La administraciòn Escolar, auxilia a los Docentes a obtener los } \\
\text { materiales necesarios, para la enseñanza en la carrera. }\end{array}$ \\
\hline 8. En su opiniòn, la mayor preocupaciòn de la administraciòn Escolar fue: \\
\hline $\begin{array}{l}\text { INSTALACIONES } \\
\text { 9. En cuanto al confort, iluminación, espacio y ventilaciòn de las } \\
\text { 10. Con respecto a la Biblioteca de la FCS, I a variedad de libros, } \\
\text { cantidad de libros, y el espacio es> }\end{array}$ \\
\hline
\end{tabular}

Figure 6. Questionnaire. Source: own elaboration.

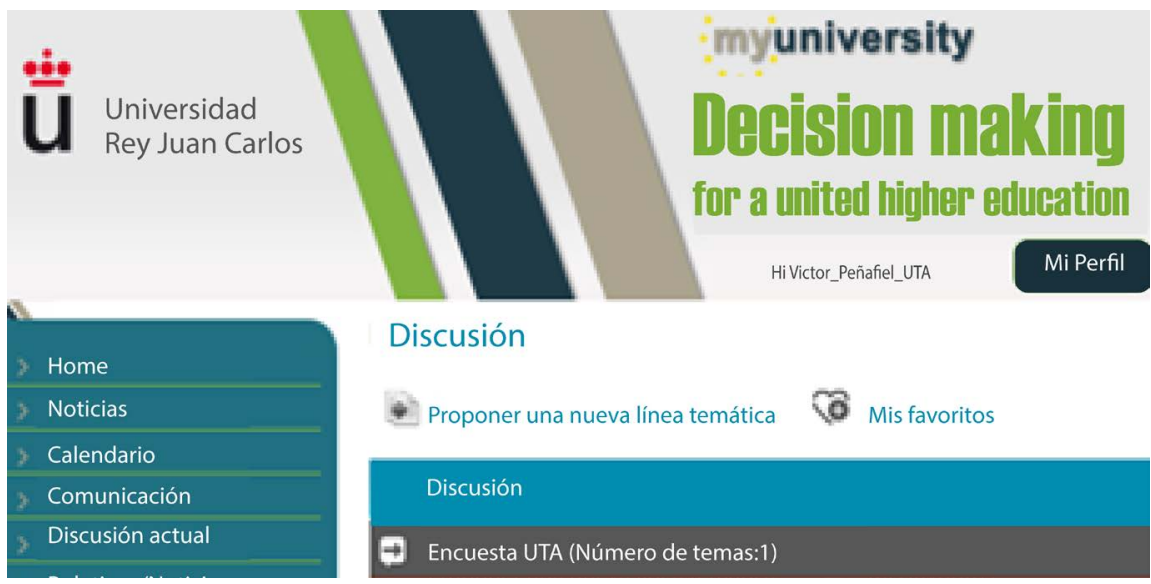

Figure 7. Survey of graduates. Source: MyUniversity-URJC.

show that integration among students was good and that the relationship with the teachers has been very good. Then, in the evaluation section of the students' process, the graduates believe that the school administration only partially assists teachers to obtain materials for the School of Medicine. Emphasizing the belief that the main concern of the school administration was rather to solve administrative problems. Finally, regarding the facilities of the Faculty as in comfort, lighting, classroom, etc. was good. As for the library, they point out that it is not suitable. Finally, we present the results of the satisfaction survey. 
According to the first question, Table 1, we see that $100 \%$ have accessed the first time use of MyUniversity-URJC.

This suggests novelty in using this type of platform.

The results of the second question in Table 2 indicate that it improves e-participation in the UTA.

We believe that the satisfaction is due to the effervescent digital culture existing in the universities.

For the results of the third question in Table 3, we display that the majority leans towards the second item, that the platform promotes debate and consensus on the web.

We see that the influence of social networks and the presence of ICT have allowed participants to be introduced in advance to this type of web tool. The reason may be the convenience to perform e-tasks from anywhere and at any time, the negative perception of the presence of hackers in the network, and the ignorance of methodologies used today for the analysis of decisions. Finally, 1.4\% considers that the platform has other advantages, such as being up-to-date on new technologies and allowing interactivity between users. It should be noted that all these advantages add up so that MyUniversity-URJC is widely accepted.

Table 1. Have you used a similar tool as MyUniversity?

\begin{tabular}{ccccc}
\hline & Options & & Frequency & Percentage \\
\hline \multirow{2}{*}{ Valid } & & Yes & 0 & 0 \\
& & No & 73 & 100.0 \\
& Total & & 73 & 100.0 \\
\hline
\end{tabular}

Source: Prepared by the authors on the basis of data supplied by MyUniversity-URJC.

Table 2. Do you think MyUniversity improves e-participation of students, teachers and authorities of the UTA?

\begin{tabular}{|c|c|c|c|}
\hline \multicolumn{2}{|c|}{ Options } & \multirow{2}{*}{$\frac{\text { Frequency }}{55}$} & \multirow{2}{*}{$\begin{array}{c}\text { Percentage } \\
75.3\end{array}$} \\
\hline & Yes & & \\
\hline \multirow[t]{3}{*}{ Valid } & No & 14 & 19.2 \\
\hline & I do not Know & 4 & 5.5 \\
\hline & & 73 & 100.0 \\
\hline
\end{tabular}

Source: Prepared by the authors on the basis of data supplied by MyUniversity-URJC.

Table 3. What advantages do you consider the MyUniversity platform has?

\begin{tabular}{ccc}
\hline Options & Frequency & Percentage \\
\hline Secure and Reliable & 10 & 13.7 \\
Promotes discussion and the consensus on the Web & 42 & 57.5 \\
Allow the access to the e-participation tasks at any time & 17 & 23.3 \\
It also promotes the structured communication & 3 & 4.1 \\
Others & 1 & 1.4 \\
Total & 73 & 100.0 \\
\hline
\end{tabular}

Source: Prepared by the authors on the basis of data supplied by MyUniversity-URJC. 
In Table 4, the fourth question among the most relevant aspects. We have the majority expressing that there is less contact with teachers, authorities, and peers. Next, the other group believes that it fosters the digital gap.

Examining the item with the highest percentage, we think that the result is because it is the first experience for all the participants in this type of event. With regard to the digital gap, we understand that there should be no presence of it in the University. As for the problems in accessing MyUniversity-URJC, it may be due to the lack of skills needed to use technology. Participants also find that there are other disadvantages, such as being easily distracted when working in the Internet and the lack of personal training to manage the platform.

The results of the fifth question in Table 5 indicate that most respondents think MyUniversity-URJC does facilitate decision-making at the University.

Analyzing what the majority expresses, we would say that there have been participants using the ICT through events executed on the platform. For example, ballots were previously used for voting; now, e-voting is used. In addition, the debate has been more simple, participatory and interesting.

In the sixth question in Table 6 we see that not all participants express that they fully agree. The other groups of users just say they agree.

Table 4. What disadvantages do you consider the Platform MyUniversity has?

\begin{tabular}{ccc}
\hline Options & Frequency & Percentage \\
\hline Less contact with professors, authorities and colleagues & 44 & 60.3 \\
Promotes the digital gap & 24 & 32.9 \\
Difficulty of access and management of the platform & 3 & 4.1 \\
Others & 2 & 2.7 \\
Total & 73 & 100.0
\end{tabular}

Source: Prepared by the authors on the basis of data supplied by MyUniversity-URJC.

Table 5. Do you think MyUniversity facilitates decision making in the University?

\begin{tabular}{|c|c|c|c|}
\hline & Options & Frequency & Percentage \\
\hline & Yes & 50 & 68.5 \\
\hline \multirow[t]{3}{*}{ Valid } & No & 13 & 17.8 \\
\hline & I do not Know & 10 & 13.7 \\
\hline & Total & 73 & 100.0 \\
\hline
\end{tabular}

Source: Prepared by the authors on the basis of data supplied by MyUniversity-URJC.

Table 6. How satisfied are you with MyUniversity?

\begin{tabular}{ccc}
\hline Options & Frequency & Percentage \\
\hline Totally agree & 39 & 53.4 \\
Agree & 20 & 27.4 \\
Not agree and not disagree & 9 & 12.3 \\
Disagree & 5 & 6.9 \\
Total & 73 & 100.0 \\
\hline
\end{tabular}

Source: Prepared by the authors on the basis of data supplied by MyUniversity-URJC. 
These results allow us to see that the degree of satisfaction is high, since the majority of participants find that MyUniversity-URJC is a reliable and secure tool.

According to the data obtained, the use of this experimental platform has shown that, indeed, it can effectively increase e-participation at the University, through the implementation of some e-tasks.

\section{Conclusions}

The use of new technologies has definitely not only altered human interaction, but also the pursuit and application of knowledge, due to the ease the Internet offers. With the exponential growth of the procedural demands through electronic means and the increasing interest of individuals to be part of the decision-making process, it makes it necessary that they are fast and remote.

To have e-participation we must take into account that not only the Internet is needed, but also it is necessary to adopt ICTs, since they can help to increase the number of individuals in the processes of public participation. These technologies can not only be used in public policy, but also in universities. Within this context we have MyUniversity-URJC, which incorporates various participation tools through a number of e-tasks. The experience of the UTA shows that not only has the web been used, but also methodologies and participation tools have been deployed on the Internet. Therefore, the web has been used to facilitate group decision-making [13].

According to the data obtained, the use of this experimental platform has shown that it, indeed, can effectively increase e-participation at the University, through the implementation of some e-tasks. The participants have also been able to demonstrate the temporary advantages and spatial data that can be obtained using this type of technological tools, like time spent and avoiding displacement at the University.

Among the advantages that the groups point out is that the platform promotes debate and consensus on the web. At the same time, the majority think it facilitates decision making at the University. We emphasize that MyUniversity not only encourages the use of ICT, but also successfully introduces methodologies for the analysis of decision-making in groups. Moreover, not only has it been highlighted by fast, convenient, and free access to participants, but also for its reliability and safety. Its interface is simple and user-friendly. Thus, the majority of participants did not have difficulties in handling MyUniversity-URJC, which reflects the dominance of the platform.

In general, the results of this experiment indicate the use of MyUniversity-URJC, as demonstrated by the satisfaction survey. Therefore, student participation has been increased and the quality of participation has improved.

\section{Acknowledgements}

We thank the Technical University of Ambato for allowing the realization of this experiment in the Campuses of Ingahurco and Huachi Chico. The European 
MyUniversity Project which is implemented within the framework: Decision making for a united higher education. Also, to MyUniversity-URJC.

\section{References}

[1] Lavín, J.M., Álvarez, E. and y Mayorga, F. (2014) Deliberation and Participation: Online Paths. Methaodos. Social Science Journal, 2, 177-179.

[2] Castells, M. and Himanen, P. (2004) The Information Society and the Welfare State. Oxford University Press, Oxford.

[3] lizzio, A. and Wilson, K. (2009) Student Participation in University Governance: The Role Conceptions and Sense of Efficacy of Student Representatives on Departmental Comités. Studies in Higher Education, 34, 69-84. https://doi.org/10.1080/03075070802602000

[4] Soler Maso, P., VilàSuñé, M., FullanaNoell, J., PlanasLladó, A. and Pallisera Diaz, M. (2011) The Opinion of Students about Their Participation in the University. 21st Century Education, 29, 323-344.

[5] Menon, M.E. (2003) Student Involvement in University Governance: A Need for Negotiated Educational Aims? Tertiary Education and Management, 9, 233-246. https://doi.org/10.1080/13583883.2003.9967106

[6] Persson, A. (2003) Student Participation in the Governance of Higher Education in Europe. Steering Committee on Higher Education and Research. Council of Europe, Strasbourg.

[7] Ríos Insua, D. and y French, S. (2010) e-Democracy: A Group Decision and Negotiation Perspective. Springer, Netherlands.

[8] Steffek, J. and y Nanz, P. (2008) Emergent Patterns of Civil Society Participation in Global and European Governance. In: Steffek, J., Kissling, C. and y Nanz, P., Eds., Civil Society Participation in European and Global Governance: A Cure for the Democratic Deficit? Palgrave Macmillan, London. https://doi.org/10.1057/9780230592506_1

[9] Lévy, P. (1994) L’Intelligence Collective. Pour une anthropologie du cyberespace. La Découverte, París.

[10] Ríos, J. and y Ríos Insua, D. (2008) A Methodology for Participatory Budget Formation. Journal Operation Research Social, 59, 203-212. https://doi.org/10.1057/palgrave.jors.2602501

[11] Papiol, Y. (2011) ICT and the eParticipation. Demos@Work: An Example of European eParticipation. Master's Thesis, pág. 41.

http://upcommons.upc.edu/pfc/bitstream/2099.1/10964/1/Memoria_Yasmina_Papi ol.pdf

[12] Salkind, N. (1999.) Methods. 3rd Edition, Prentice Hall Hispanic America, Inc., México.

[13] Levy, P. (1995) L’Intelligence Collective. Dunod, Paris. 
Submit or recommend next manuscript to SCIRP and we will provide best service for you:

Accepting pre-submission inquiries through Email, Facebook, LinkedIn, Twitter, etc. A wide selection of journals (inclusive of 9 subjects, more than 200 journals)

Providing 24-hour high-quality service

User-friendly online submission system

Fair and swift peer-review system

Efficient typesetting and proofreading procedure

Display of the result of downloads and visits, as well as the number of cited articles Maximum dissemination of your research work

Submit your manuscript at: http://papersubmission.scirp.org/

Or contact sn@scirp.org 